\title{
A REVIEW OF EFFECT OF WELDING AND POST WELD HEAT TREATMENT ON MICROSTRUCTURE AND MECHANICAL PROPERTIES OF GRADE 91 STEEL
}

\author{
Merchant Samir $\mathbf{Y}^{1}$ \\ ${ }^{1}$ Lecturer, Fabrication Technology Department, Sir B.P. Institute, Bhavnagar, Gujarat, India
}

\begin{abstract}
Today getting high thermal efficiency in thermal and nuclear power plant is a big challenge. Many new material are developed. SA 335 grade 91 steel is modified high chrome-moly martenstitic steel. This material is having excellent toughness and high temperature creep strength. During welding, this material is having tremendous change in its microstructure and hence mechanical property. Many research works were done in this area. This paper discusses weld ability of P91 material. Effect of different welding process, type of filler wire, its chemical composition and type of flux is discussed in this paper. PWHT is necessary after welding of P91 steel. PWHT temperature and its duration affects phase transformation and mechanical properties of weld metal, HAZ and parent metal. Major focus is given on hardness, creep resistance and notch toughness.
\end{abstract}

Keywords - P91, Welding, Microstructure, Toughness, Creep, Hardness, PWHT

\section{INTRODUCTION}

The major problem of steam power plant is its requirement of double heating of steam for produce steam of temperature above $600^{\circ} \mathrm{C}$ and 300 bar pressure. The $\mathrm{CO}_{2}$ omission is the second big problem. So it is necessary to develop such a material which can produce steam at $500^{\circ} \mathrm{C}$ to $600^{\circ} \mathrm{C}$ temperature and pressure of $180-300$ bar. Increase in thermal efficiency of material can reduce $\mathrm{CO}_{2}$ emission by $20 \%$ due to reduce in focil fuel consumption. For such application a material should have high strength at elevated temperature and good oxidation corrosion resistance at elevated temperature. This led to development of $\mathrm{Cr}-\mathrm{Mo}$ martenstitic steel with $\mathrm{Cr} 1$ to $12 \%$. Other element required to improve corrosion and creep resistance are $\mathrm{Nb}, \mathrm{V}, \mathrm{Mo}$ and $\mathrm{W}$. This allows the operating temperature from $560^{\circ} \mathrm{C}$ to $650^{\circ} \mathrm{C}$. For this $9 \mathrm{Cr}-1 \mathrm{Mo}-0.2 \mathrm{~V}$ steel is very popular which is known as P91 steel [1]. P91 material is widely used in fabrication of process equipment for nuclear and steam power plant. P91 material is having very good creep resistance and corrosion resistance at elevated temperature. This material is having low thermal coefficient of expansion. The steel ASTM A335 Gr. P91 is a high-Cr martenstitic heat-resistant steel and is applied particularly to large diameter thick-walled pipes in thermal power plants [2]. The chemical composition and mechanical properties of P91 material are in Table-1 \& Table2 [3][4]. Fig 1 shows microstructure of P91 steel [5].

****.

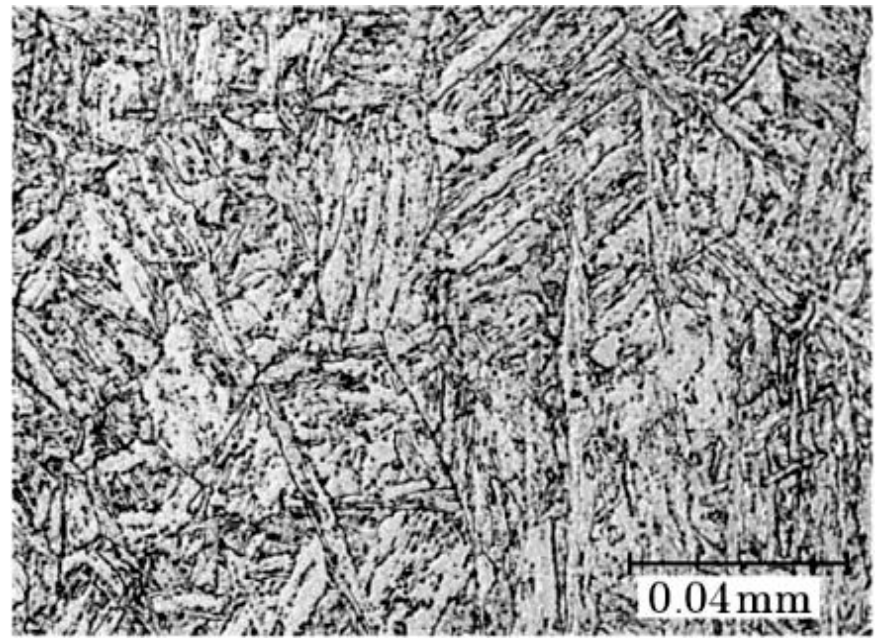

Fig.1 Microstructure of P91 steel, etched state (2\%HNO3+ ethyl alcohol), light microscope, magnification 500X [5]

\section{WELDING OF P91 STEEL}

\subsection{Weldability P91 Steel:}

P91 steel material is selected for its better creep resistance property at elevated temperature. But during welding this property is detoriated. With increase in $\mathrm{Cr} \%$ from 1 to $12 \%$ microstructure of weld metal and HAZ varies from ferritic to fully martenstitic. Weld may also contain some amount of delta-ferrite. The weld joint becomes very hard. Preheating is not having that much influence on the weld joint hardness. Due to high harden ability of P91 steel weld joint makes it susceptible for cold cracking. So P91 steel weld joint needs a PWHT immediately after completion of welding [6]. PWHT is to be carried out at optimal temperature. For heavy thickness weld joint if PWHT is not done at optimal temperature, creep and creep resistance properties may 
suffered. Air quenching of P91 is done to produce tempered martensite in combination with vanadium nitride, niobium carbonitride and $\mathrm{M}_{23} \mathrm{C}_{6}$ type carbide particles [7]. Composition of weld fusion zone is determined chemical composition of base metal, filler metal and percentage of dilution. Heat affected zone is adjacent to weld fusion zone which is having different micro structural and mechanical properties than base metal and weld metal. In creep rupture testing this HAZ fails at low stress level as type IV fracture. Softening zone and fine grain particle zone is having less creep resistance than the reaming base metal. So the weld joint becomes susceptible to premature type IV creep failure. A PWHT becomes helpful in improvement of weld joint from type IV failure [2][8][9]. It was observed that rupture location of weld joint of P91 steel shifted from weld metal at higher stress condition to fine grain HAZ adjacent to base metal zone at a lower stress condition [10].

\subsection{Selection of Welding Process}

Selection of welding process for P91 steel depends on welding position, plate thickness, filler metal, flux, shielding gas composition and PWHT temperature and duration. Following welding processes may be used [3]
1) GTAW
2) SMAW welding
3) MAG - welding massive wire
4) MAG - welding core wire
5) SAW
6) FCAW

If we compare welding of P91 steel by GTAW and SMAW process hardness of weld metal is more in case of GTAW but hardness of HAZ and base metal is less as compared to SMAW process. Fig-2 shows the hardness profile of weld joint by both processes [11][12]. By GTAW process toughness of weld metal can be achieved up to $220 \mathrm{~J}$ at $20^{\circ} \mathrm{C}$ because of high purity of microstructure and less content of absorbed oxygen into weld metal. GTAW process produce small weld bead. By SMAW toughness 50J to $95 \mathrm{~J}$ at $20^{\circ} \mathrm{C}$ can be achieved after adequate PWHT. Therefore SMAW process can be used to achieve minimum toughness value 47 J specified by EN 1557 : 1999. By SAW process a wide and scattered range of weld metal toughness $35 \mathrm{~J}$ to $70 \mathrm{~J}$ at $20^{\circ} \mathrm{C}$ can be achieved. So this process can produce weld joint having some shortfall of requirement of $47 \mathrm{~J}$. SAW process can be selected for achieving high productivity. By FCAW process toughness can be achieved up to $25 \mathrm{~J}$ to $35 \mathrm{~J}$ at $20^{\circ} \mathrm{C}$. This is less than the required toughness of 47J. So satisfactory impact toughness can be achieved by PWHT at $760^{\circ} \mathrm{C}$ for 4 to 5 hours. In FCAW process content of oxygen weld metal may be upto $600 \mathrm{ppm}$ to $1000 \mathrm{ppm}$. Due to this weld joint hardness increase and toughness decrease. To reduce oxidation silicon content increase up to $0.3 \%$ this tends to increase in $\delta$-ferrite phase. A shielding gas $\mathrm{Ar}-\mathrm{CO}_{2}$ (80-20) to $\mathrm{Ar}-\mathrm{CO}_{2}$ (95-5) can be used. This improve toughness $10 \%$ and reduce oxygen level less than $100 \mathrm{ppm}$. Table-3 shows the toughness requirement of P91 weld joint as per European specification BS EN 1599: 1997 [13].

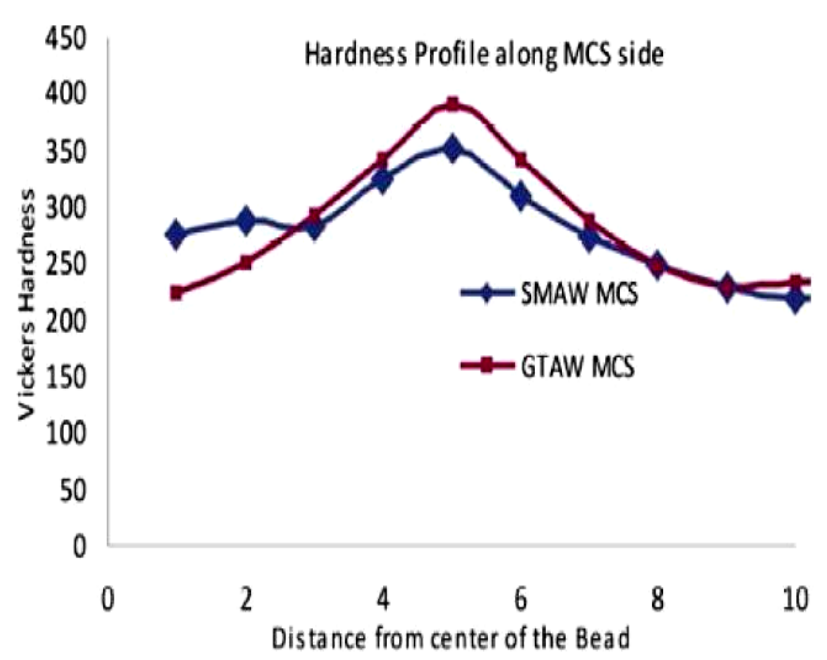

Fig-2 Hardness profile for SMAW and GTAW along medium carbon steel side [12]. The distance shown on the X-axis is in $\mathrm{mm}$.

\subsection{Consumable}

A good quality P91 weld joint can be obtained only when proper chemical composition of weld metal is obtained. For SAW process basic flux is preferred over other types of flux to avoid contamination of molten weld metal by oxygen and nitrogen. For SMAW electrode selected for P91 steel is E9015-B9-H4. It contains 0.08-0.13\% C, $1.25 \% \mathrm{Mn}, 0.3 \% \mathrm{Si}$, $0.1 \% \mathrm{~S}$ and $\mathrm{P}$ each, $1 \% \mathrm{Ni}, 8-10.5 \% \mathrm{Cr}$, and $0.85-1.2 \% \mathrm{Mo}$. Additional elements are $\mathrm{V}, \mathrm{Cu}, \mathrm{Al}, \mathrm{Nb}$, and $\mathrm{N}$ in small amount. The welding polarity selected is DCEP. The main thing of this electrode is that it contains very low hydrogen less than $4 \mathrm{ml}$ per $100 \mathrm{gms}$ of weld metal. Backing of electrode is strongly recommended. Though P91 material is having hardening problem during welding, it is very highly susceptible for hydrogen induced crack (HIC) [14][15].

\subsection{Welding Procedure}

Generally P91 steel is welded with $400-550 \mathrm{~F}$ preheat and inter pass temperature. Weld joint is slowly cooled in air up to $200^{\circ} \mathrm{F}$ which is slightly less than $\mathrm{Mf}$ temperature $212^{\circ} \mathrm{F}$. Then it is followed by PWHT. Care must be taken that austenite will transform to martensite before PWHT, otherwise it will transform in martensite after PWHT which makes weld joint hard and reduce its toughness. For automatic welding root run is welded with GTAW and followed by FCAW or SAW of getting high production rate. Welding of wide flat bead with slight weaving and high travel speed is selected. After welding dye penetrate test is done in same manner like with other material. But special attention is given to this material for its high HIC susceptibility. PWHT immediately is performed after welding [14][15]. Table-4 shows metal toughness and hardness obtained by welding from GTAW, SMAW, GTAW and GMAW processes [13]. 


\section{POST WELD HEAT TREATMENT OF P91}

\section{STEEL}

\subsection{Post Weld Heat Treatment}

After welding of P91 material PWHT is required without considering the thickness. It is very much essential part of fabrication process to obtain sound weld joint properties. For a small tubes PWHT is required at $750^{\circ} \mathrm{C}$ to $775^{\circ} \mathrm{C}$ for 2 hours holding time. Generally the socking temperature for PWHT of P91 material is less than the lower critical temperature i.e. $788^{\circ} \mathrm{C}$ but due to error of operator or thermo couple if temperature goes above lower critical temperature than P91 material shows very erratic behavior. Above lower critical temperature martensite of P91 material once again convert in austenite and than during cooling it will convert in untempered martensite which is hard and brittle. In such case reheating is required. After welding the weld joint is cooled up to preheat temperature which is less than Mf temperature than heat treatment is done. Due to this austenite convert in martensite and this martensite will convert in tempered martensite during heat treatment. If the cooling temperature is reduced up to room temperature than all the austenite may convert in martensite but the problem of hydrogen induced cracking may observed. So it is not advisable. PWHT cycle may adopted for P91 steel shown in table - 5 [12][15][17][18].

Table -5 PWHT Cycle For P91 Material Hating Below A-1 Temperature

\begin{tabular}{|l|l|l|}
\hline Sr No. & Description & Value \\
\hline 1 & Heating rate & $40^{\circ} \mathrm{C} /$ hour \\
\hline 2 & Socking temperature & $740-775^{\circ} \mathrm{C}$ \\
\hline 3 & Socking time & $2-8$ hours \\
\hline 4 & Cooling rate & $80^{\circ} \mathrm{C} /$ hour \\
\hline 5 & Unloading temperature & $300^{\circ} \mathrm{C}$ \\
\hline
\end{tabular}

\subsection{Effect of PWHT on Microstructure of P91 Steel:}

Fig 3 (A),(B),(C),(D) shows the microstructure of $\mathrm{P} 91$ as unwelded base metal, as welded metal, after PWHT at $760^{\circ} \mathrm{C}$ for 3 hours and after PWHT at $760^{\circ} \mathrm{C}$ for $6 \mathrm{hrs}[1]$.

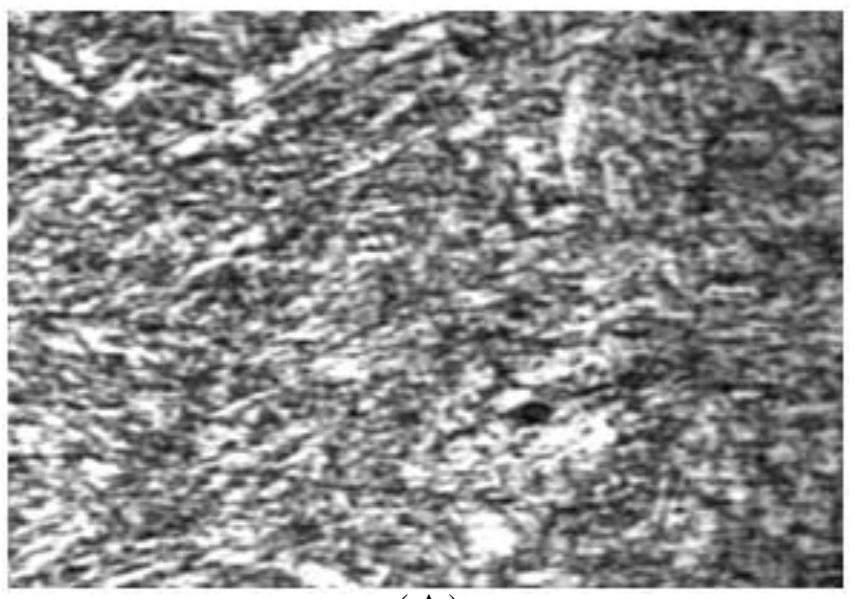

(A)

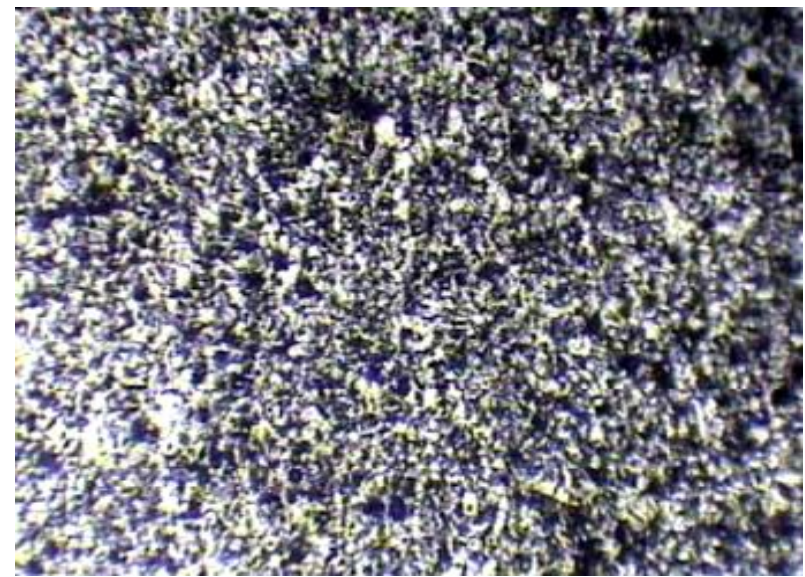

( B )

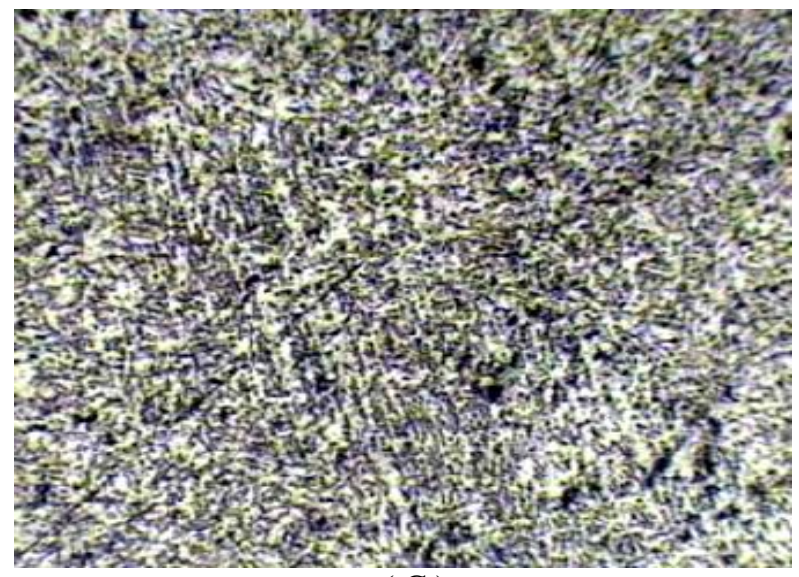

( C )

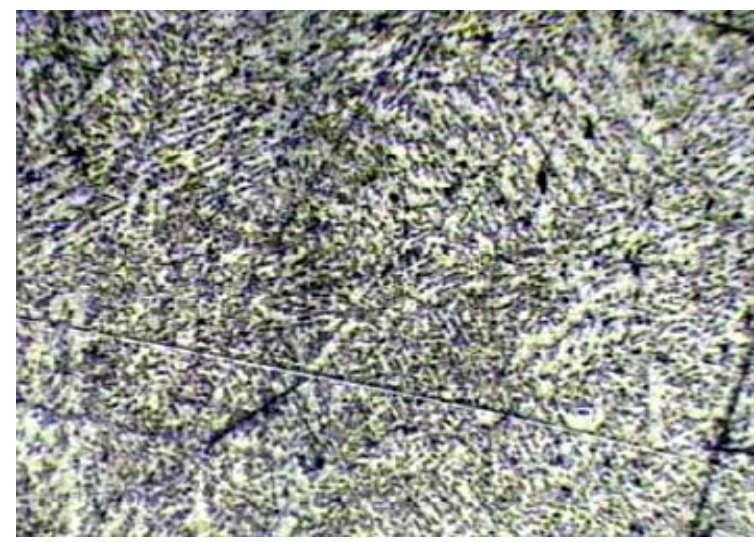

( D )

Fig.-3 Optical Micrograph of P91 weld joint [1].

From microstructure it is observed that in as received base metal P91 metal is having fully tempered martensite microstructure. After welding some ferrite flakes can be observed. After PWHT at $760^{\circ} \mathrm{C}$ for 3 hours the ferrite distribution in martensite becomes more uniform. This shows grain structure refinement. This will improve toughness of weld metal and HAZ [1][18]. 


\subsection{Influence of $\delta$-Ferrite Phase on P91 Weld Joint:}

During welding of P91 material $\delta$-ferrite phase is produce in the weld joint. Due to the presence of $\delta$-ferrite phase toughness of weld joint decrease. As per EN 1557 : 1999, required toughness for the $\mathrm{P} 91$ weld joint for a successful hydro test is 47 Joules at room temperature of $20^{\circ} \mathrm{C}$ [19]. Weld toughness is influenced by welding process, chemical composition of filler metal, shielding gas used, PWHT temperature and duration of PWHT. If volume of $\delta$-ferrite is increased above $2 \%$, toughness is reduced significantly [20][21][22]. Fig 4 shows presence of $\delta$-ferrite in tempered martensite matrix of P91 as welded joint [23]. FCAW welding with F4 type flux is having high silicon content compare to SMAW electrode. Silicon is a very powerful ferrite stabilizer. Due to this $\delta$-ferrite is more in case of welding with FCAW welding process. As welded joint microstructure is having needle like grain structure. Hence hardness of joint increase and toughness is decreased. With increase in PWHT duration this grain structure changes and quantities of precipitates increase shown in fig-5 [23]. Scheider formula is used to calculate $\mathrm{Cr}_{\text {eq. }}$ and $\mathrm{Ni}_{\text {eq. }}$ is as under :

$$
\begin{aligned}
& \mathrm{Cr}_{\mathrm{eq}}=\mathrm{Cr}+2 \mathrm{Si}+1.5 \mathrm{Mo}+5 \mathrm{~V}+1.75 \mathrm{Nb}+0.75 \mathrm{~W} \\
& \mathrm{Ni}_{\mathrm{eq}}=\mathrm{Ni}+0.5 \mathrm{Mn}+30 \mathrm{C}+25 \mathrm{~N}+0.3 \mathrm{Cu}
\end{aligned}
$$

Ferrite factor $=\mathrm{Cr}_{\mathrm{eq}}-\mathrm{Ni}_{\mathrm{eq}}$

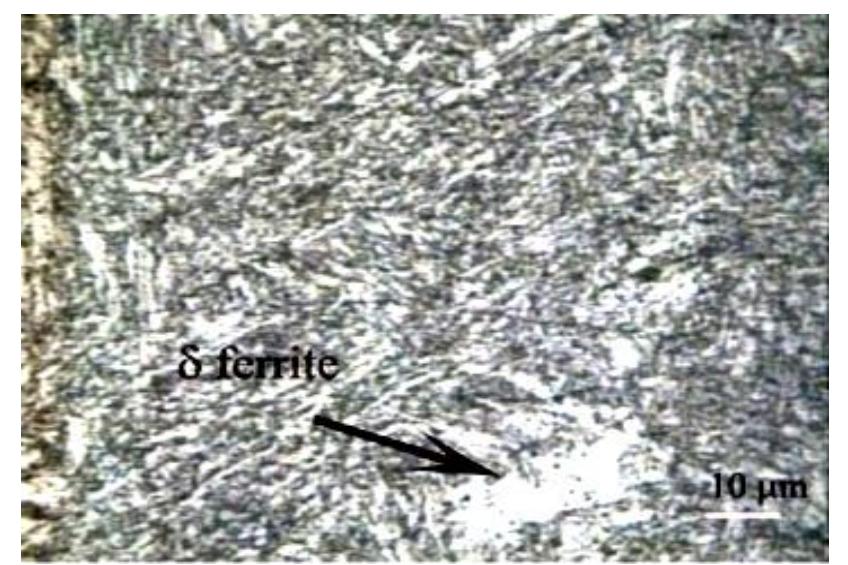

Fig- 4 Presence of $\delta$-ferrite in tempered martensite matrix of P91 as welded joint [23].

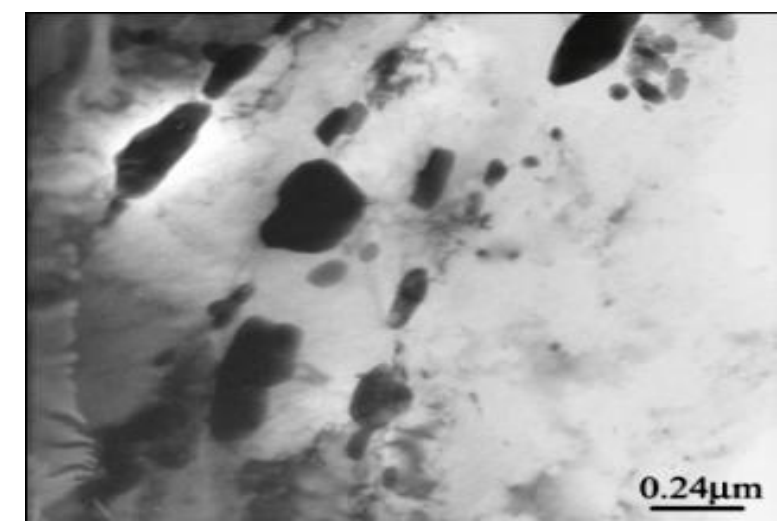

(a)

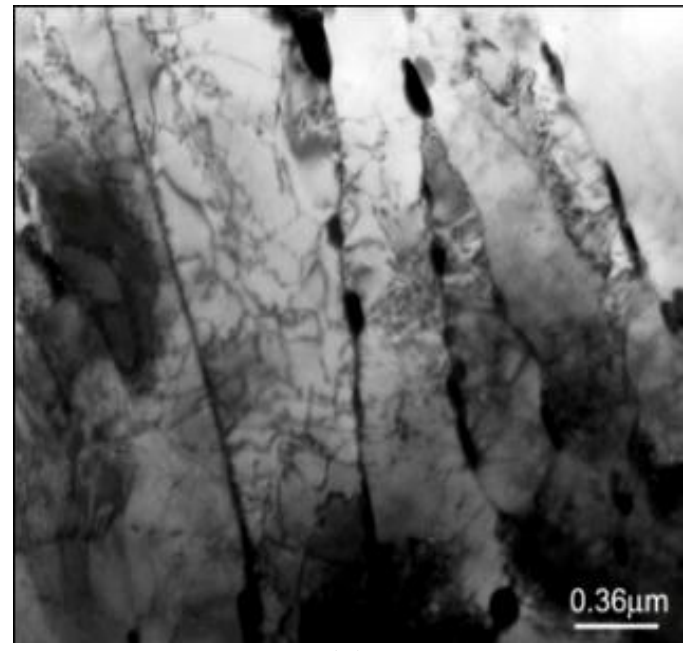

(b)

Fig.5 Influence of PWHT duration on microstructure of welds (a) $760^{\circ} \mathrm{C}$ for $2 \mathrm{hr}$ (b) $760^{\circ} \mathrm{C}$ for $5 \mathrm{hr}$ [23]

To obtain fully martensitic microstructure value of $\mathrm{Cr}_{\mathrm{eq}}$ is more than 13.5 and the difference between Creq and $\mathrm{Ni}_{\text {eq }}$ is less than $8 . \mathrm{V}$ and $\mathrm{Nb}$ is reducing the toughness of weld joint and if they are present when welding with acidic flux the toughness decreases more. To counterbalance it PWHT duration is to be increased. In acidic flux system micro inclusions are more and coarser $(>5 \mu \mathrm{m})$ compare to basic flux inclusion system $(<5 \mu \mathrm{m})$. The coarser micorinclusions behaves like needle and in connection with $\mathrm{V}+\mathrm{Nb}$ reduce toughness of weld. So acidic flux system can incorporate the $\mathrm{V}+\mathrm{Nb}$ up to $0.18 \%$ wt. maximum compare to basic flux system $0.31 \%$ wt. $\mathrm{V}+\mathrm{Nb}$ and flux system are having more significant effect on P91 weld joint toughness 47 Joules compare to ferrite factor. With increase in PWHT temperature and duration, $\delta$-ferrite phase is decreased [23].

\section{EFFECT OF WELDING AND PWHT ON} MECHANICAL PROPERTIES

\subsection{Hardness:}

Hardness of HAZ of P91weld joint is over $350 \mathrm{Hv}$. This hardness level is the limiting hardness value for most of the carbon steel. The reasons for this high harness of weld joint is presence of alloying element and formation of martensite in weld metal and HAZ. At this high hardness if hydrogen dissolved in weld metal, it can produced hydrogen induced crack. After PWHT at temperature $750^{\circ} \mathrm{C}$ for hardness of weld joint is reduced. With increase in PWHT duration from 2 hours to 6 hours hardness of P91 weld metal and HAZ reduce due to phase transformation from martensite to ferrite [18]. As shown in fig-6, with increase in PWHT temperature hardness of P91 steel is decreased but its rate of decrease in hardness is reduced as temperature increase from $750^{\circ} \mathrm{K}$ to $1040^{\circ} \mathrm{K}$ for $1 \mathrm{hr}[12]$. 


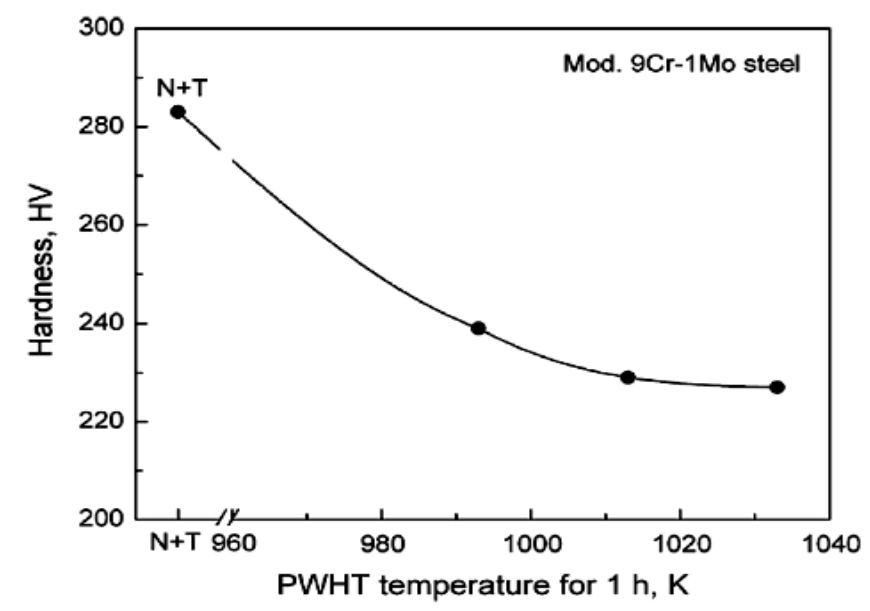

Fig.6 Relation between PWHT temperature and hardness [12]

\subsection{Creep}

Many power plant pipes are failed in services due to creep at high temperature. In pipes working at high pressure and temperature in power plant, type IV cracks due to creep develops in HAZ. During creep test of P91 pipe welded joint at $625^{\circ} \mathrm{C}$, it was observed that type IV creep crack was produced in the HAZ low temperature zone near the parent metal. Thus by making HAZ properties uniform and matched with parent metal the type IV creep failure can be reduced [24]. With increase in PWHT from $600^{\circ} \mathrm{C}$ to $760^{\circ} \mathrm{C}$ temperature, minimum and average creep rate is increased. After rise in PWHT temperature above $820^{\circ} \mathrm{C}$ minimum and average creep rate is sharply increased. With increase in PWHT temperature from $600^{\circ} \mathrm{C}$ and duration $2 \mathrm{hrs}$ to $840^{\circ} \mathrm{C}$ and duration $8 \mathrm{hrs}$ creep rate increased and creep resistance decreased [2]. If weld joint is normalized and cooled up to $200^{\circ} \mathrm{C}$ then tempered, it has lowest creep rate [17].

\subsection{Toughness}

Impact toughness of P91 material is very much required for applying hydrostatic pressure. In power generation plant high pressure steam is essential at above $600^{\circ} \mathrm{C}$. Impact toughness of P91 weld metal is decreased very rapidly in as welded condition. This shortfall can be improved by PWHT. Applying PWHT at $760^{\circ} \mathrm{C}$ for 3 hours can improve toughness equal to base metal. With increase in PWHT duration impact toughness is increased further. Fig-7 shows the effect of PWHT on impact toughness [1].

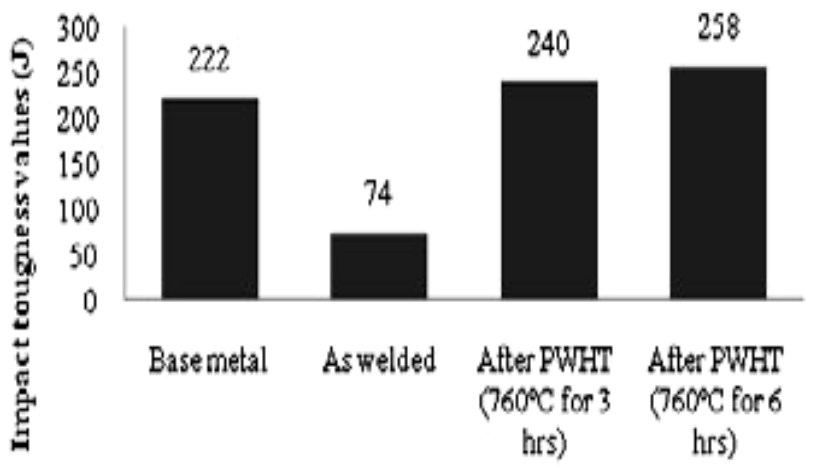

Source

Fig.- 7 Effect of PWHT on impact toughness [1].

\section{CONCLUSION}

After review of work of many researcher in the field of welding and PWHT of P91 steel following conclusions have been obtained :

1. Welding process and selection of consumable affects the microstructure and mechanical properties of $\mathrm{P} 91$ steel.

2. PWHT is necessary to improve microstructure and mechanical properties of P91 steel. It produce more homogeneous microstructure in weld metal and HAZ. It reduce crack susceptibility of weld metal.

3. With increase in PWHT temperature and duration tempering of P91 steel occurred. So tempered martensite is produced. Due to it hardness, tensile strength are decreased and ductility, impact toughness above $47 \mathrm{~J}$ are increased.

4. If PWHT temperature increases than lower critical temperature, creep strain rate and creep ductility increases and rupture time decreases. Rupture location moves towards weld fusion zone. Precipitation and growth of carbide particles increases with increase in PWHT temperature above A1 line. $\delta$-ferrite phase increase with increases in PWHT temperature so creep resistance and toughness both are decreased. Re-tempering decreases creep rate.

5. Increasing number of cycle of PWHT does not give any significant benefit on mechanical properties of P91 weld metal. Only PWHT cycle with appropriate socking temperature and duration is sufficient.

6. PWHT at $750^{\circ} \mathrm{C}$ is best suited for maintaining uniform hardness of base metal, HAZ and weld metal. It neither increases hardness of weld metal nor softness of base metal.

\section{REFERENCES}

[1] Devinder Pal Singh, Mithlesh Sharma, Jaspal Singh Gill, "Effect of Post Weld Heat Treatment on the Impact Toughness and Microstructural Property", IJRMET Volume-3, Issue- 2, May - Oct-2013, pp 216-219. 
[2] Dr. Leijun Li, "Effect of Post-Weld Heat Treatment on Creep Rupture Properties of Grade 91 Steel Heavy Section Welds", Mechanical \& Aerospace Engineering, Utah State University (435)797-8184, 2012.

[3] Material data sheet, editor Thyssenkrupp Materials International Gmbh, Technical Sales / Quality_Management, Am Thyssenhaus 1.

[4] ASME sec II-A, Boiler And Pressure Vessel Code, Ferrous Material Specification, SA 335 / SA 335M, pp 573 -584.

[5] Katarzyna Makowska , Zbigniew L. Kowalewski, Boleslaw Augustyniak, Leszek Piotrowski "Determination Of Mechanical Properties Of P91 Steel By Means Of Magnetic Barkhausen Emission", Journal Of Theoretical And Applied Mechanics, Warsaw. Volume-52, Issue-1, 2014, pp. 181-188.

[6] "Welding Technology For Engineers", Editors : Baldev raj, V Shankar \& A. K. Bhaduri, Narosa Publishing House, third reprint - 2009, pp 22-36.

[7] Hattestrand, M., and Andren, H., 2001, "Evaluation Of Particle Size Distributions Of Precipitates In A 9\% Chromium Steel Using Energy filtered Transmission Electron Microscopy", Micron, Volume-32, pp 789. 797

[8] Newell, N., 2007, "Guideline for Welding Creep Strength-Enhanced Ferritic Alloys”, EPRI, March 2007.

[9] Tabuchi, M., et al, 2001, "Creep Crack Growth Behavior In The HAZ Of Weldment Of W Containing High Cr Steel", Intl J. Pressure Vessels and Piping, Volume-78, pp 779-784.

[10] Watanabe, T.,M. Tabuchi, M. Yamazaki, T. Tanabe and H. Hongo , "Creep Damage Evaluation Of 9Cr-1MoV-Nb Steel Welded Joints Showing Type IV Fracture", Intl. J. Pressure Vessels and Piping, 83, 2005, pp 6371.

[11] Husnain Shabir, Khalid. H. Hashmi, Ghulam Zakria, Shahid Khalil, Mahboob Alam and Muhammad Farooq, "Characterization Of Dissimilar Alloys Welding Techniques With Enhanced Galvanic Corrosion", World Applied Sciences Journal, 29, 2014, pp. 89-95.

[12] Jonas Ohlsson, "Effects of different heat treatments on hardness of Grade 91 steel", karlstand Univeristy, 2014.

[13] Z Zhang*, J C M Farrar* and A M Barnes**, "Weld Metals for P91 - Tough Enough?", * Metrode Products Limited, U.K, **TWI Ltd., U.K.

[14] Siddharth Pant and Swati Bhardwaj, "Properties and Welding Procedure for Grade 91 Alloy Steel", International Journal of Engineering Research and Technology, Volume 6, Number 6 (2013), pp. 767 772.

[15] Sperko Engineering Services, Inc. “ Welding "Grade 91" Alloy Steel”, May, 2007, pp 1-5.

[16] B.K. Choudhary, J. Christopher, D.P. Rao Palaparti, E. Isaac Samuel, M.D. Mathew, "Influence of temperature and post weld heat treatment on tensile stress-strain and work hardening behaviour of modified 9Cr-1Mo steel", Materials and Design, Volume-52, 2013, pp. 58-65.

[17] M. L. Santella, R. W. Swindeman, R. W. Reed and J. M. Tanzosh, "Martensite formation in $9 \mathrm{Cr}-1$ Mo steel weld metal and its effect on creep behavior",Oak Ridge National Laboratory, Oak Ridge, Tennessee 37831, Babcock \& Wilcox Company, Barberton, Ohio 44203.

[18] Nattaphon TAMMASOPHON, Weerasak HOMHRAJAI, Gobboon LOTHONGKUM, "Effect of Postweld Heat Treatment on Microstructures and Hardness of TIG, Weldment between P22 and P91 Steels with Inconel 625 Filler Metal " Journal of Metals, Materials and Minerals, Volume-21, Issue-1, pp.93-99, 2011.

[19] E. L. Bergquist, Consumables And Welding Modified 9Cr-1 Mo Steel. Svetsaren, (1 -2), 1999, 2 -5.

[20] M. Sireesha, S. K. Albert, and S. Sundaresan, "Microstructure And Mechanical Properties Of Weld Fusion Zones In Modified 9Cr-1 Mo Steel". Journal of Materials Engineering Performance, Volume-10, Issue- 3, 2001, 320 - 330.

[21] J. Onoro, "Martensite Microstructure Of 9 - 12\% Cr Steel Weld Metals", Journal of Materials Processing Technology, Volume-180, 2006, pp-137 -142.

[22] Barnes, "The Influence Of Composition On Micro Structural Development And Toughness Of Modified 9\%Cr-1 Mo Weld Metals", TWI report, 509/ 1995, 1995.

[23] B. Arivazhagan, M. Kamaraj, "A Study On Influence Of D-Ferrite Phase On Toughness Of P91 Steel Welds", White Paper, Steel-Grips.Com 2013, pp.19-24.

[24] T.H. Hyde, A.A. Becker, W. Sun, A. Yaghi, J.A. Williams and S. Concari, "Determination Of Creep Properties For P91 Weldment Materials At 625”, 5th International Conference on Mechanics and Materials in Design, Porto-Portugal, 24-26 July 2006, pp 1-13.

\section{BIOGRAPHY}

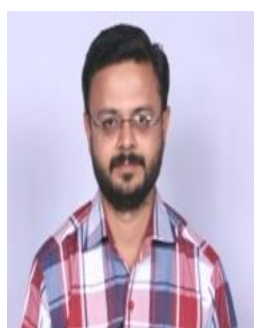

Samir Y. Merchant is working as a senior lecturer in Fabrication Technology Department, Sir Bhavsinhji Polytechnic Institute, Bhavnagar, Gujarat, India since 2004. He obtained M.E. Mechanical Engineering ( Production Engineering) from M.S. University, Vadodara with First Rank in 2010 
Table -1 Chemical Composition Of P-91 Material

\begin{tabular}{|l|l|l|l|l|l|l|l|l|l|l|l|l|}
\hline Element & $\mathrm{C}$ & $\mathrm{Si}$ & $\mathrm{Mn}$ & $\mathrm{P}$ & $\mathrm{S}$ & $\mathrm{Al}$ & $\mathrm{Cr}$ & $\mathrm{Mo}$ & $\mathrm{Ni}$ & $\mathrm{V}$ & $\mathrm{N}$ & $\mathrm{Nb}$ \\
\hline Percent & $0.08-$ & $0.2-$ & $0.3-$ & $\leq 0.02$ & $\leq 0.01$ & $\leq 0.04$ & $8-9.5$ & $0.85-$ & $\leq 0.4$ & $0.18-$ & $0.03-$ & $0.06-$ \\
& 0.12 & 0.5 & 0.6 & & & & & 1.05 & & 0.25 & 0.07 & 0.1 \\
\hline
\end{tabular}

Table-2 Mechanical Properties Of P-91 Material

\begin{tabular}{|l|l|l|l|l|}
\hline Yield strength & Tensile strength & Elongation & Impact energy at 20 C & Hardness HRC \\
\hline $415 \mathrm{~N} / \mathrm{mm}^{2}$ & $\leq 585 \mathrm{~N} / \mathrm{mm}^{2}$ & $20 \%$ & $220 \mathrm{~J}$ & 25 \\
\hline
\end{tabular}

Table-3 Mechanical Property Requirements for Weld Metals of Various Specifications for P91 Material [13]

\begin{tabular}{|c|c|c|c|c|c|c|c|c|c|}
\hline Type & Specification & $\begin{array}{l}\text { Shielding } \\
\text { Gas }\end{array}$ & $\begin{array}{l}\text { Tensile } \\
\text { strength } \\
\text { MPa }\end{array}$ & $\begin{array}{l}\text { Yield } \\
\text { strength } \\
\text { at } 0.2 \% \\
\text { Offset } \\
\text { MPa }\end{array}$ & $\begin{array}{l}\text { Elongatio } \\
\mathrm{n} \%\end{array}$ & $\begin{array}{l}\text { Toughness } \\
\text { requirement } \\
@ 20^{\circ} \mathrm{C} \\
\text { Avg/Min. J }\end{array}$ & $\begin{array}{l}\text { Preheat and } \\
\text { interpass } \\
\text { temperature, } \\
{ }^{\circ} \mathrm{C}\end{array}$ & $\begin{array}{l}\text { Postweld } \\
\text { condition }\end{array}$ & $\begin{array}{l}\text { PWHT } \\
\text { procedure }\end{array}$ \\
\hline $\begin{array}{l}\text { Parent } \\
\text { steel }\end{array}$ & Type-91 & & $585-850$ & 415 & 20 & $(>41)$ & & & $730-780{ }^{\circ} \mathrm{C}$ \\
\hline $\begin{array}{l}\text { Covered } \\
\text { electrode }\end{array}$ & $\begin{array}{l}\text { BS EN } \\
\text { 1599:1997; } \\
\text { ECrMo91B }\end{array}$ & & 585 & 415 & 17 & $47 / 38^{a}$ & 200-300 & PWHT & $\begin{array}{l}750-770{ }^{\circ} \mathrm{C} \\
2 \text { to } 3 \text { hrs }\end{array}$ \\
\hline Solid wire & $\begin{array}{l}\text { Pr EN } \\
\text { 12070:1996; } \\
\text { CrMo91 }\end{array}$ & & 585 & 415 & 17 & $47 / 38^{a}$ & $250-350$ & PWHT & $\begin{array}{l}750-760{ }^{\circ} \mathrm{C} \\
3 \mathrm{hrs}\end{array}$ \\
\hline $\begin{array}{l}\text { Covered } \\
\text { electrode } \\
\& \text { solid } \\
\text { wire }\end{array}$ & $\begin{array}{l}\text { GEC- Alsthom } \\
30 / 658\end{array}$ & & \multicolumn{5}{|c|}{$\begin{array}{l}\text { No mechanical property specified, but expected to exceed the parent } \\
\text { steel properties }\end{array}$} & PWHT & \\
\hline $\begin{array}{l}\text { Covered } \\
\text { electrode }\end{array}$ & $\begin{array}{l}\text { AWS A5.5-96 } \\
\text { E90XX-B91 }\end{array}$ & & 620 & 530 & 17 & Not specified ${ }^{b}$ & $232-288$ & PWHT & $\begin{array}{l}730-760{ }^{\circ} \mathrm{C} \\
1 \mathrm{hrs}\end{array}$ \\
\hline Solid wire & $\begin{array}{l}\text { AWS A5.28-96 } \\
\text { ER90S-B9 }\end{array}$ & $\begin{array}{l}\text { Argon }^{\mathrm{C}} \\
5 \% \mathrm{O}_{2}\end{array}$ & 620 & 410 & 16 & Not specified ${ }^{b}$ & $150-260$ & PWHT & $\begin{array}{l}730-760{ }^{\circ} \mathrm{C} \\
1 \mathrm{hrs}\end{array}$ \\
\hline
\end{tabular}

Table-4 Weld Metal Toughness And Hardness Properties Of Various Processes [13]

\begin{tabular}{|l|l|l|l|l|l|}
\hline \multirow{2}{*}{ Process } & $\begin{array}{l}\text { Consumable } \\
\text { type }\end{array}$ & Size, $\mathrm{mm}$ & $\begin{array}{l}\text { Typical impact } \\
\text { energy at ambient } \\
\text { temperature, J }\end{array}$ & $\begin{array}{l}\text { Typical lateral } \\
\text { expansion at } \\
\text { ambient temp. } \\
\text { mm }\end{array}$ & $\begin{array}{l}\text { Typical } \\
\text { hardness, HV } \\
(10 K g)\end{array}$ \\
\hline \multirow{2}{*}{ GTAW } & Solid wire & 2.4 & $100-240$ & $2.0-2.5$ & $240-260$ \\
\cline { 2 - 6 } & MCW & 1.2 & $100-150$ & $1.8-2.1$ & $240-260$ \\
\hline \multirow{2}{*}{ SMAW } & $\begin{array}{l}\text { Covered } \\
\text { electrode }\end{array}$ & $2.5,3.2,4.0,5.0$ & $30-90$ & $0.7-2$ & $230-250$ \\
\hline \multirow{2}{*}{ SAW } & Solid wire & 2.4 & $30-70$ & $0.5-1.0$ & $240-260$ \\
\cline { 2 - 6 } & MCW & 1.6 & $25-70$ & $0.4-0.8$ & $240-260$ \\
\hline \multirow{2}{*}{ GMAW } & FCW & 1.2 & $10-40$ & $0.15-0.6$ & $230-270$ \\
\cline { 2 - 3 } & MCW & $1.2,1.6$ & $30-40$ & $0.4-0.5$ & $240-260$ \\
\hline $\begin{array}{l}\text { PWHT - 755-760 }{ }^{\circ} \mathrm{C} \times 2-5 \text { hours followed by furnace cool. } \\
\text { MCW - Metal Core Wire } \\
\text { FCW - Flux Core Wire }\end{array}$ &
\end{tabular}

